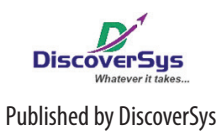

Published by DiscoverSys

\section{Analysis of Inpatients Food Leftover at Sanglah Hospital Bali Province}

\author{
Ni Luh Partiwi Wirasamadi, ${ }^{1,4^{*}}$ Kadek Tresna Adhi, ${ }^{2,4}$ I Wayan Weta ${ }^{1,3,4}$
}

\section{ABSTRACT}

Background and purpose: Foods leftover is still very common in many hospitals in Indonesia. Minimum standard of hospitals require that foods leftover of patient is not more than $20 \%$. The aim of this study was to determine the number and cost wasted due to the foods leftover of patient. Methods: The study was cross-sectional involving 68 inpatient subjects in the 1st, 2nd and 3rd ward class and hospitalized up to 10 days and had regular food with a 10-day menu cycle. Data of foods leftover were obtained by three methods: observation, medical records and interview. Foods leftover were measured by Visual Comstock method with the scale of 6 points. Age, sex, length of stay, ward classes, and types of patients' diseases were obtained from medical records. Patient's perception of food appearance and taste were gained through interviews. Data were analyzed by independent sample t-test and one-way ANOVA.
Results: Average number of patients' food leftover amounted to $14.79 \%$. Patients who left foods were mostly women, aged 50-64 years, hospitalized in the class 2 nd and 3 rd with a length of stay $\leq 5$ days. Those who had good perception on appearance and taste of the food tended to leave less food leftovers. The average cost of meal wasted a day was $\mathrm{Rp} 2,939$ per patient. There were significant different leftover foods according to gender, age group, length of stay, ward classes, and the patient's perception $(p<0,05)$, whereas there were no significant different leftover foods according to the type of diseases and the menu cycles $(p>0,05)$.

Conclusion: Average number of patients' food leftover at Sanglah Hospital Denpasar has satisfied hospital minimum standard (less than $20 \%$ ) with an average daily cost of meal wasted was Rp 2,939 per patient.

Keywords: leftover food, wasted costs, Sanglah Hospital Bali

Cite This Article: Wirasamadi, N.L.P., Adhi, K.T., Weta, I.W. 2015. Analysis of Inpatients Food Leftover at Sanglah Hospital Bali Province. Public Health and Preventive Medicine Archive 3(1): 72-77. D0I:10.15562/phpma.v3i1.91

\title{
Analisis Sisa Makanan Pasien Rawat Inap di RSUP Sanglah Denpasar Provinsi Bali
}

${ }^{1}$ Sanglah Public General Hospital, ${ }^{2} S$ chool of Public Health Faculty of Medicine Udayana University, ${ }^{3}$ Department of Community and Preventive Medicine Faculty of Medicine, Udayana University, ${ }^{4}$ Public Health Postgraduate Program Udayana University

\section{${ }^{*}$ Correspondence to:}

Ni Luh Partiwi Wirasamadi, Sanglah

Public General Hospital, Public Health Postgraduate Program Udayana University partiwiwirasamadiniluh1971@ gmail.com
Hasil: Rata-rata jumlah sisa makanan pasien sebesar 14,79\%. Pasien yang menyisakan makanan lebih banyak adalah pasien perempuan, umur 50-64 tahun, dirawat di Kelas 2 dan 3 dengan lama rawat $\leq 5$ hari. Pasien yang menilai penampilan dan rasa makanan baik cenderung menyisakan makanan lebih sedikit. Rata-rata biaya makan terbuang sehari sebesar Rp 2.939 per pasien. Dijumpai adanya perbedaan bermakna sisa makanan menurut jenis kelamin, kelompok umur, lama rawat, kelas perawatan, dan persepsi pasien $(p<0,05)$. Tidak ada perbedaan bermakna menurut jenis penyakit dan siklus menu $(p>0,05)$.

Simpulan: Rata-rata jumlah sisa makanan pasien di RSUP Sanglah Denpasar sudah memenuhi standar pelayanan minimal rumah sakit yaitu kurang dari $20 \%$ dengan rata-rata biaya makan terbuang sehari sebesar Rp. 2.939 per pasien.

Kata Kunci: sisa makanan, biaya terbuang, RSUP Sanglah Bali

Kutip artikel ini: Wirasamadi, N.L.P., Adhi, K.T., Weta, I.W. 2015. Analisis Sisa Makanan Pasien Rawat Inap di RSUP Sanglah Denpasar Provinsi Bali. Public Health and Preventive Medicine Archive 3(1): 72-77. D01:10.15562/phpma.v3i1.91 


\section{PENDAHULUAN}

Makanan yang tersisa masih sering dijumpai di berbagai rumah sakit di Indonesia. Beberapa penelitian yang dilakukan di rumah sakit (RS) di Indonesia menunjukkan bahwa rata-rata sisa makanan sangat bervariasi antara 17\%-67\%. ${ }^{1}$ Penelitian di RS Hasan Sadikin Kota Bandung didapatkan sisa makanan lunak sebesar $31,2 \%^{2}$ sedangkan di RS Dr. Sardjito Yogyakarta dijumpai rata-rata sisa makan pagi sebesar 23,41\%. ${ }^{3}$ Di kota Palu sisa makanan di RS Jiwa Madani pada waktu makan siang yaitu nasi sebesar 24,48\%." Berdasarkan Kepmenkes No.129/Menkes/SK/ II/2008 tentang Standar Pelayanan Minimal Rumah Sakit (SPM), sisa makanan yang tidak termakan oleh pasien sebanyak-banyaknya $20 \%$. Terpenuhinya syarat tersebut menjadi indikator keberhasilan pelayanan gizi di setiap rumah sakit di Indonesia. ${ }^{5}$ Berdasarkan beberapa teori dan dari hasil penelitian terdahulu, terjadinya sisa makanan diakibatkan beberapa faktor yang berasal dari pasien, makanan dan lingkungan., ${ }^{3,4,6,7}$

Adanya sisa makanan mengakibatkan asupan nutrisi pasien tidak adekuat dan secara ekonomis menunjukkan banyaknya biaya yang terbuang. Pasien dengan asupan gizi yang tidak adekuat jika dibiarkan dalam jangka waktu yang lama mempunyai risiko 2,4 kali untuk terjadi malnutrisi pada pasien di rumah sakit. ${ }^{8}$ Sedangkan adanya biaya yang terbuang menyebabkan anggaran makanan kurang efisien dan efektif sehingga pengelolaan biaya makan tidak mencapai tujuan yang optimal. Karena itu manajemen rumah sakit menghendaki pengelolaan makanan yang efektif dan kurang efisien. Efektif dalam artian upaya pemenuhan gizi pasien selama sakit sesuai dengan tujuan yang sudah ditetapkan dan efisien berarti hemat dalam penggunaan sumber daya yang ada.

Di RSUP Sanglah Denpasar, kegiatan penyelenggaraan makanan mengacu pada Peraturan Pemberian Makanan Rumah Sakit (PPMRS) yaitu suatu pedoman dalam memberikan pelayanan gizi yang disesuaikan dengan kondisi dan kemampuan rumah sakit. Berdasarkan aturan tersebut, macam menu yang ditetapkan terdiri dari menu standar untuk Kelas 1, 2 dan 3 dengan siklus menu 10 hari, dan menu pilihan yang berlaku di Kelas VVIP/VIP. Salah satu indikator mutu pelayanan gizi sesuai dengan PPMRS adalah tidak boleh lebih dari 20\% pasien yang menyisakan makanan $\geq 25 \%$. Berdasarkan hasil pengamatan di Triwulan I, II dan III tahun 2013, terdapat 22,9\% pasien Kelas 3 yang menyisakan makanan $\geq 25 \%$. Sedangkan jumlah sisa makanan jika dibandingkan dengan standar pelayanan minimal Kemenkes dan jumlah biaya yang terbuang dari sisa makanan belum diketahui karena selama ini belum pernah dilakukan penelitian di RSUP Sanglah.

Penelitian ini bertujuan untuk mengetahui jumlah sisa makanan dan biaya yang terbuang dari sisa makanan dengan harapan dapat digunakan sebagai bahan evaluasi bagi pelayanan gizi agar dalam perencanaan bisa lebih efisien dan lebih efektif.

\section{METODE}

Penelitian ini adalah survei sampel cross-sectional dengan jumlah sampel sebanyak 68 pasien yang dipilih secara consecutive di RSUP Sanglah selama Bulan Pebruari-Maret 2015. Pengumpulan data dilakukan di ruang rawat Kelas 1, 2 dan 3. Penelitian di Kelas 1 dilakukan di Ruang Flamboyan, di Kelas 2 di Ruang Ratna dan di Kelas 3 di Ruang Angsoka 1, Angsoka 2 dan Angsoka 3. Ruangan-ruangan tersebut digunakan untuk merawat pasien dari berbagai bagian/divisi seperti penyakit dalam, onkologi, urologi, syaraf, mata, kebidanan dan orthopedi. Subyek penelitian adalah pasien rawat inap di kelas tersebut yang mendapatkan makanan biasa standar rumah sakit dan memenuhi kriteria. Makanan biasa standar rumah sakit adalah makanan yang diberikan kepada pasien yang tidak memerlukan diet khusus karena penyakitnya, dengan makanan pokok nasi dan siklus menu 10 hari. Kriteria inklusi adalah pasien umur 13-64 tahun, dirawat minimal 2 hari, dalam kondisi sadar, dan bersedia berpartisipasi dalam penelitian. Kriteria eksklusi meliputi pasien di ruang geriatri, immunocompromise, intensif dan menular dan pasien yang mengalami perubahan diet dari makanan biasa ke bentuk lain selama perawatan. Besar sampel minimal sebanyak 68 orang dihitung dengan rumus besar sampel proporsi tunggal, dengan nilai proporsi pasien yang menyisakan makanan (p) sebesar 22,9\%, tingkat presisi (d) sebesar $10 \%$ dan tingkat kemaknaan $\alpha=5 \%$.

Data dikumpulkan dengan tiga cara yaitu observasi sisa makanan, rekam medis dan wawancara. Data tentang sisa makanan diperoleh dengan Metode Visual Comstock skala 6 poin. Data tentang umur, jenis kelamin, lama rawat, kelas rawat, dan jenis penyakit pasien diperoleh dari rekam medis. Data tentang persepsi pasien berkaitan dengan penampilan dan rasa makanan diperoleh dengan wawancara. Wawancara dilakukan satu kali oleh peneliti di ruang rawat setelah pasien dinyatakan boleh pulang oleh dokter. Data siklus menu didapatkan dari pedoman menu yang berlaku di Instalasi Gizi tahun 2015. Pedoman berisi macam menu yang disajikan dalam siklus 10 harian, meliputi siklus menu ke-1 yang berlaku untuk tanggal 1, 11 dan 21, siklus menu ke-2 untuk tgl 2, 
12 dan 22, demikian seterusnya hingga siklus menu ke-10 untuk tanggal 10, 20 dan 30. Persepsi pasien tentang penampilan makanan adalah penilaian pasien mengenai warna, bentuk, besar porsi dan cara penyajian makanan. Persepsi pasien tentang rasa makanan adalah penilaian pasien mengenai aroma, bumbu, suhu dan tingkat kematangan, yang selanjutnya dikategorikan menjadi persepsi baik dan persepsi kurang. Persepsi dinyatakan baik jika jumlah skor $\geq 75 \%$, dan dinyatakan kurang jika jumlah skor $<75 \%$. Sisa makanan diukur dengan metode Visual Comstock skala 6 poin setiap makan pagi, siang dan sore serta makanan selingan (snack) pagi dan sore selama perawatan maksimal 10 hari. Metode Visual Comstock terdiri dari skor $0(0 \%)$ jika tidak ada makanan yang tersisa, skor $1(25 \%)$ jika tersisa $1 / 4$ porsi, skor $2(50 \%)$ jika tersisa $1 / 2$ porsi, skor $3(75 \%)$ jika tersisa $3 / 4$ porsi, skor $4(95 \%)$ jika tersisa hampir mendekati utuh dan skor 5 $(100 \%)$ jika tersisa semua atau utuh. Pemilihan metode ini dengan pertimbangan waktu lebih singkat, tidak memerlukan alat yang banyak dan rumit, menghemat biaya dan dapat mengetahui sisa makanan menurut jenisnya. Hasil penelitian yang dilakukan oleh Comstock ${ }^{9}$ menunjukkan adanya hubungan yang kuat antara taksiran visual skala Comstock dan penimbangan $(r=0,93)$. Hubungan yang kuat ini juga diketemukan oleh Murwani ${ }^{10}$ dalam laporan penelitian di RSUP Dr. Sardjito Yogyakarta.

Biaya sisa makanan dihitung dan dinyatakan dalam rupiah berdasarkan konversi rata-rata persentase sisa semua jenis makanan dengan harga kontrak bahan makanan antara RSUP Sanglah dengan perusahaan pemasok. Normalitas data untuk semua variabel numerik diuji dengan kolmogorov-smirnov test dan menunjukkan distribusi normal $(\mathrm{p}>0,05)$. Analisis data kuantitatif dengan independent sampel t-test dilakukan untuk membandingkan sisa makanan berdasarkan variabel dengan dua kategori (jenis kelamin, lama rawat dan persepsi pasien tentang penampilan dan rasa makanan rumah sakit); dan one-way ANOVA untuk membandingkan sisa makanan berdasarkan variabel yang lebih dari dua kategori (kelompok umur, kelas perawatan, dan kelompok penyakit). Dinyatakan ada perbedaan rata-rata sisa makanan jika hasil uji menunjukkan nilai $\mathrm{p}<0,05$. Penelitian ini mendapat kelaikan etik dari Komisi Etik Fakultas Kedokteran Universitas Udayana/Rumah Sakit Umum Pusat Sanglah Denpasar.

\section{HASIL}

Pada Tabel 1 disajikan karakteristik responden dan data sisa makanan. Sebagian besar pasien berjenis kelamin perempuan $(58,8 \%)$, dengan rata-rata umur 38,75 tahun $(\mathrm{SD}=13,97)$ dengan kisaran umur 16-63 tahun. Sebagian besar pasien dirawat di Kelas 3 (82,4\%) dengan distribusi kelompok penyakit terbanyak adalah onkologi (39,7\%). Lama rawat berkisar antara 2-18 hari dengan rata-rata 6,8 hari $(\mathrm{SD}=3,58)$. Rata-rata jumlah sisa makanan pasien sebesar $14,79 \%(\mathrm{SD}=10,43)$, dan dijumpai adanya perbedaan sisa makanan yang bermakna menurut jenis kelamin, kelompok umur, kelas rawat dan lama rawat $(\mathrm{p}<0,05)$, tetapi tidak ada perbedaan menurut kelompok penyakit ( $>0,05)$. Pasien yang menyisakan makanan lebih banyak memiliki karakteristik perempuan, berusia 50-64 tahun, dirawat di Kelas 2 dan 3 dan dengan lama rawat $\leq 5$ hari. Pengelompokan umur pasien didasarkan pada Angka Kecukupan Gizi (AKG) yang dianjurkan tahun $2014 .^{11}$

Berdasarkan penilaian pasien terhadap makanan rumah sakit, diketahui mayoritas pasien menilai baik terhadap penampilan dan rasa makanan rumah sakit (Tabel 2). Analisis statistik menunjukkan ada perbedaan sisa makanan yang bermakna $(p<0,05)$ antara pasien yang menilai penampilan dan rasa makanan sudah baik dengan pasien yang menilai penampilan dan rasa makanan masih kurang. Data tersebut menunjukkan rerata jumlah sisa makanan sebesar $22,14 \%$ pada pasien yang menilai penampilan makanan kurang dan rata-rata jumlah sisa makanan sebesar $23,86 \%$ pada pasien yang menilai rasa makanan kurang.

Tidak ada perbedaan sisa makanan menurut siklus menu $(p>0,05)$, meskipun terlihat siklus ke-1 dan ke-7 menyisakan makanan lebih banyak seperti terlihat pada Tabel 3. Rerata biaya yang terbuang dari sisa makanan pasien sebesar Rp. $2.939(\mathrm{SD}=2,185)$ per orang per hari, atau sebesar $14,61 \%$ dari harga menu.

\section{DISKUSI}

Rerata sisa makanan pasien sebesar $14,79 \%$. Hasil ini masih lebih rendah jika dibandingkan dengan penelitian oleh Djamaludin ${ }^{3}$ di RS Dr. Sardjito Yogyakarta yang menunjukkan sisa makanan biasa masih di atas 20\%. Begitu juga penelitian Dian $^{7}$ di RS Puri Cinere Depok yang menunjukkan sisa makanan biasa sebesar 21,4\%. Berdasarkan hasil pengamatan mutu pelayanan gizi di RSUP Sanglah tahun 2013 dengan menggunakan standar PPMRS adalah proporsi pasien yang menyisakan makanan $\geq 25 \%$ sebesar $22,9 \%$. Hal ini berbeda dengan penelitian saat ini dimana yang dihitung adalah rata-rata persentase sisa makanan pasien. Sesuai dengan SPM, sisa makanan yang tidak termakan oleh pasien di RSUP Sanglah sudah memenuhi 
Tabel 1 Rerata (mean) sisa makanan berdasarkan karakteristik responden

\begin{tabular}{|c|c|c|c|}
\hline \multirow[b]{2}{*}{ Variabel } & \multirow[b]{2}{*}{ n (\%) } & \multirow{2}{*}{$\begin{array}{c}\text { Rerata persen sisa makanan } \\
\text { Rerata persen (SD) }\end{array}$} & \multirow[b]{2}{*}{ Nilai $p$} \\
\hline & & & \\
\hline \multicolumn{4}{|l|}{ Jenis kelamin } \\
\hline Laki-laki & $28(41,2)$ & $12,04(\mathrm{SD}=7,76)$ & 0,047 \\
\hline Perempuan & $40(58,8)$ & $16,72(\mathrm{SD}=11,65)$ & \\
\hline \multicolumn{4}{|c|}{ Kelompok umur (tahun) } \\
\hline $16-18$ & $7(10,3)$ & $10,57(\mathrm{SD}=7,55)$ & \\
\hline $19-29$ & $15(22,1)$ & $16,67(\mathrm{SD}=11,31)$ & \\
\hline $30-49$ & $27(39,7)$ & $12,15(\mathrm{SD}=9,87)$ & 0,037 \\
\hline $50-64$ & $19(27,9)$ & $18,63(\mathrm{SD}=10,49)$ & \\
\hline \multicolumn{4}{|c|}{ Kelas perawatan } \\
\hline Kelas 1 & $10(14,7)$ & $8,10(\mathrm{SD}=9,37)$ & 0,030 \\
\hline Kelas 2 & $2(2,9)$ & $18,00(\mathrm{SD}=7,07)$ & \\
\hline Kelas 3 & $56(82,4)$ & $15,87(\mathrm{SD}=10,37)$ & \\
\hline \multicolumn{4}{|c|}{ Kelompok penyakit } \\
\hline Interna & $11(16,2)$ & $14,27(\mathrm{SD}=9,09)$ & 0,832 \\
\hline Mata & $3(4,4)$ & $14,33(\mathrm{SD}=6,81)$ & \\
\hline Obgyn & $3(4,4)$ & $20,00(\mathrm{SD}=8,54)$ & \\
\hline Onkologi & $27(39,7)$ & $15,26(\mathrm{SD}=10,28)$ & \\
\hline Orthopedi & $11(16,2)$ & $11,91(\mathrm{SD}=9,63)$ & \\
\hline Syaraf & $7(10,3)$ & $12,71(\mathrm{SD}=8,85)$ & \\
\hline Urologi & $6(8,8)$ & $19,00(\mathrm{SD}=18,79)$ & \\
\hline \multicolumn{4}{|c|}{ Lama perawatan (hari) } \\
\hline$\leq 5$ & $29(42,6)$ & $15,76(\mathrm{SD}=12,00)$ & 0,026 \\
\hline$>5$ & $39(57,4)$ & $14,08(\mathrm{SD}=9,19)$ & \\
\hline Rerata sisa & & $14,79(\mathrm{SD}=10,43)$ & \\
\hline
\end{tabular}

Tabel 2 Rerata (mean) sisa makanan berdasarkan persepsi pasien

\begin{tabular}{lccc}
\hline & & Rerata persen sisa makanan & \\
Variabel & $\mathbf{n}(\%)$ & Rerata (SD) & Nilai p \\
\hline Persepsi penampilan & & & 0,001 \\
Baik & $61(89,7)$ & $22,14(\mathrm{SD}=17,68)$ & \\
Kurang & $7(10,3)$ & & 0,001 \\
Persepsi rasa & & $10,15(\mathrm{SD}=6,35)$ & \\
Baik & $45(66,2)$ & $23,86(\mathrm{SD}=10,97)$ & \\
Kurang & $23(33,8)$ & & \\
\hline
\end{tabular}

standar pelayanan minimal rumah sakit yaitu $\leq 20 \%$. Hal ini juga menunjukkan semakin baiknya mutu pelayanan gizi yang diberikan. Semakin baik pelayanan gizi yang diberikan oleh rumah sakit, merupakan salah satu hal yang mendukung RSUP Sanglah untuk bisa lulus akreditasi international JCI maupun akreditasi nasional (KARS).

Sisa makanan pasien di Kelas 2 dan 3 lebih banyak dibandingkan dengan di Kelas 1 . Menu yang diberikan sama namun pasien di ruang rawat Kelas
1 mendapatkan penyajian makan dengan piring keramik yang terdiri dari piring nasi, piring lauk, mangkok sayur dan piring snack serta pemberian garnish/hiasan pada wadah makanan. Di Kelas 2 dan 3 alat makan yang digunakan berupa plato melamin. Menurut Nuryati, ${ }^{12}$ penggunaan dan pemilihan alat makan yang tepat dalam penyusunan makanan akan mempengaruhi penampilan makanan yang disajikan dan mempengaruhi pasien dalam menghabiskan makanannya. Hal ini 
Tabel 3 Rerata (mean) sisa makanan dan rata-rata biaya terbuang dari sisa makanan pasien per siklus menu

\begin{tabular}{|c|c|c|c|c|}
\hline \multirow{2}{*}{$\begin{array}{l}\text { Siklus } \\
\text { menu }\end{array}$} & \multirow{2}{*}{$\begin{array}{c}\begin{array}{c}\text { Persentase sisa } \\
\text { makanan* }\end{array} \\
\text { Rerata (SD) }\end{array}$} & \multirow{2}{*}{$\begin{array}{c}\begin{array}{c}\text { Biaya sisa } \\
\text { (Rupiah) }\end{array} \\
\text { Rerata (SD) }\end{array}$} & \multirow{2}{*}{$\begin{array}{c}\text { Harga menu } \\
\text { (Rupiah) }\end{array}$} & \multirow{2}{*}{$\begin{array}{c}\text { Persentase biaya sisa } \\
\text { terhadap harga menu } \\
\text { Rerata (SD) }\end{array}$} \\
\hline & & & & \\
\hline 1 & $15,24(\mathrm{SD}=12,90)$ & $3.268(\mathrm{SD}=2.960)$ & 19.356 & $17,91(\mathrm{SD}=15,15)$ \\
\hline 2 & $13,38(\mathrm{SD}=11,35)$ & $2.633(\mathrm{SD}=2.587)$ & 18.960 & $13,89(\mathrm{SD}=13,64)$ \\
\hline 3 & $13,16(\mathrm{SD}=11,04)$ & $2.382(\mathrm{SD}=2.113)$ & 18.867 & $12,24(\mathrm{SD}=11,24)$ \\
\hline 4 & $13,10(\mathrm{SD}=15,11)$ & $2.538(\mathrm{SD}=3.020)$ & 20.187 & $12,15(\mathrm{SD}=14,88)$ \\
\hline 5 & $14,37(\mathrm{SD}=11,52)$ & $2.723(\mathrm{SD}=2.332)$ & 19.167 & $14,65(\mathrm{SD}=12,09)$ \\
\hline 6 & $14,62(\mathrm{SD}=14,02)$ & $2.995(\mathrm{SD}=3.014)$ & 18.439 & $16,24(\mathrm{SD}=16,35)$ \\
\hline 7 & $16,44(\mathrm{SD}=12,15)$ & $3.369(\mathrm{SD}=2.728)$ & 19.641 & $16,69(\mathrm{SD}=13,98)$ \\
\hline 8 & $13,44(\mathrm{SD}=11,22)$ & $2.279(\mathrm{SD}=1.995)$ & 17.896 & $12,36(\mathrm{SD}=10,98)$ \\
\hline 9 & $13,14(\mathrm{SD}=11,21)$ & $2.818(\mathrm{SD}=2.579)$ & 19.578 & $15,05(\mathrm{SD}=13,09)$ \\
\hline 10 & $10,93(\mathrm{SD}=11,10)$ & $2.480(\mathrm{SD}=2.314)$ & 18.429 & $14,95(\mathrm{SD}=12,35)$ \\
\hline Rerata & $13,86(\mathrm{SD}=12,16)$ & $2.939(\mathrm{SD}=2.185)$ & 19.052 & $14,61(\mathrm{SD}=11,27)$ \\
\hline
\end{tabular}

* One-way ANOVA $(\mathrm{p}=0,927)$

sesuai dengan hasil wawancara mengenai persepsi pasien terhadap penampilan makanan rumah sakit yang mendapatkan hasil bahwa di Kelas 1 tidak ada pasien yang menilai kurang untuk penyajian makanan sementara di Kelas 2 dan 3 sebanyak $10,3 \%$ menilai kurang, kemungkinan disebabkan karena adanya perbedaan alat makan tersebut.

Padavariabel persepsipasien tentang penampilan dan rasa makanan rumah sakit ditemukan ada perbedaan sisa makanan. Pasien yang menyatakan rasa dan penampilan makanan baik cenderung menyisakan makanan yang lebih sedikit. Hal serupa juga dilaporkan oleh Dian, ${ }^{7}$ bahwa pasien yang berpendapat penampilan makanan tidak menarik akan lebih banyak menyisakan makanan. Pada penelitian ini, sebagian besar pasien menilai penampilan makanan sudah baik. Tetapi di Kelas 2 dan 3 masih terdapat penilaian kurang dalam hal cara penyajian dan besar porsi. Pemberian diet kepada pasien dengan makanan biasa tidak menggunakan standar perhitungan kebutuhan zat gizi sehingga kemungkinan porsi makanan yang diberikan lebih kecil dari kebutuhan.

Rasa makanan adalah aspek penilaian makanan yang sulit dinilai secara akurat karena bersifat sangat subyektif, tergantung selera pasien yang mengkonsumsinya. Pada penelitian ini, sebagian besar responden menyatakan rasa makanan sudah baik. Dari keseluruhan aspek rasa makanan yang masih mendapat penilaian kurang yaitu aspek kesesuaian bumbu-bumbu. Jika dihubungkan dengan siklus menu di instalasi gizi, belum semua jenis menu memiliki standar resep yang dipakai acuan dalam mengolah makanan. Dalam perencanaan menu di rumah sakit diperlukan adanya peraturan pemberian makanan rumah sakit, standar porsi, standar resep dan standar bumbu. ${ }^{13}$

Sisa makanan selain menyebabkan kebutuhan gizi pasien tidak adekuat juga menyebabkan adanya biaya yang terbuang. Rerata biaya terbuang per orang per hari sebesar Rp 2.939,00 atau 14,61\% dari total harga menu (food cost). Jumlah ini lebih besar dari penelitian di RS Dr. Sardjito Yogyakarta yang menunjukkan total biaya makan yang terbuang per orang per hari sebesar Rp. 1.265,08 atau 10,79\% dan di RS Jiwa Madani Palu biaya terbuang per orang per hari sebesar Rp. 1.529,33 atau 9,97\%. ${ }^{3,4}$ Besarnya biaya sisa makanan dipengaruhi oleh besarnya harga satuan dari bahan makanan dan banyaknya sisa makanan. Perbedaan besar biaya terbuang ini kemungkinan karena harga bahan makanan di masing-masing daerah berbeda, dan juga jenis bahan makanan yang tersisa. Harga kontrak bahan makanan di RSUP Sanglah menggunakan harga rata-rata survei pasar di Kota Denpasar yang fluktuasinya cukup tinggi.

Jumlah biaya yang terbuang, jika dibandingkan dengan rata-rata jumlah pasien yang mendapatkan makanan biasa pada saat penelitian berlangsung yaitu 120-150 orang per hari maka total biaya makan yang terbuang dalam setahun diperoleh sebesar Rp. 160.910.250,00. Jumlah ini jika dibandingkan dengan realisasi anggaran makan dalam setahun untuk pasien Kelas 1, 2 dan 3, maka rata-rata persentase biaya terbuang dari sisa makanan biasa sebesar $4,3 \%$. Jumlah biaya terbuang hendaknya ditekan seminimal mungkin sehingga pengelolaan biaya makan mencapai tujuan yang optimal. Hal lain yang bisa dilakukan adalah mengevaluasi siklus menu 10 hari menjadi 7 hari sehingga pengulangan bahan makanan tidak terjadi. Hal ini 
mungkin agak sulit dilakukan karena rata-rata lama rawat pasien 6,8 hari, sehingga siklus 7 hari cukup efektif dan efisien dalam artian pasien tidak akan mendapat pengulangan menu yang sama dari hari pertama dirawat sampai pasien pulang. Demikian juga perbaikan penampilan makanan di Kelas 2 dan 3 agar disamakan dengan di Kelas 1 dengan menggunakan piring sehingga mengurangi sisa makanan di kelas tersebut. Penyusunan standar resep untuk memperbaiki rasa makanan sehingga bisa mengurangi jumlah sisa makanan. Di RSUP Sanglah selain makanan biasa, dalam sehari instalasi gizi melayani sekitar 500-600 pasien per hari, dengan berbagai macam diet yang belum pernah diteliti mengenai sisa makanannya.

Keterbatasan penelitian ini adalah tidak memperhitungkan pemberian obat yang mungkin mempengaruhi nafsu makan, dan kemungkinan makanan dimakan oleh keluarga pasien meskipun sudah dijelaskan sebelumnya dalam protokol penelitian. Hal ini dapat mempengaruhi jumlah sisa makanan dan menimbulkan bias dalam melakukan analisis sisa makanan. Penelitian ini sudah mampu menjelaskan sisa makanan biasa di Kelas 1, 2 dan 3, namun pasien dengan makanan biasa hanya sekitar $25 \%$ dari seluruh pasien yang ada di RS Sanglah, sehingga pasien yang memperoleh jenis makanan lain belum bisa terjangkau dalam penelitian ini.

\section{SIMPULAN}

Rerata jumlah sisa makanan pasien di RSUP Sanglah Denpasar sudah memenuhi standar pelayanan minimal rumah sakit yaitu kurang dari $20 \%$. Biaya terbuang dari sisa makanan dalam sehari rata-rata sebesar Rp. 2.939,-- per pasien. Sebagian besar pasien menyatakan baik pada penampilan dan rasa makanan rumah sakit. Sisa makanan berbeda menurut jenis kelamin, kelompok umur, lama perawatan, kelas perawatan, persepsi pasien tentang penampilan dan rasa makanan, akan tetapi tidak berbeda menurut jenis penyakit dan siklus menu.

\section{UCAPAN TERIMA KASIH}

Ucapan terima kasih penulis sampaikan kepada Direktur Utama RSUP Sanglah Denpasar yang telah memberikan ijin penelitian dan dukungan dana untuk terselenggaranya penelitian ini. Ucapan terimakasih juga disampaikan kepada ahli gizi ruangan yang telah membantu dalam proses pelaksanaan penelitian dan para pasien yang menjadi responden yang telah berpartisipasi pada penelitian ini.

\section{DAFTAR PUSTAKA}

1. Zakiyah L. Plate Waste among Hospital Inpatients. Malaysian Journal of Public Health Medicine 2005; 5(2): 19-24

2. Munawar A. Hubungan Makanan, Rasa Makanan dan Faktor Lainnya dengan Sisa Makanan (Lunak) Pasien Kelas 3 di RSUP Dr. Hasan Sadikin Bandung. (tesis). Jakarta: Universitas Indonesia; 2011

3. Djamaluddin M. Analisis Zat Gizi dan Biaya Sisa Makanan Pada Pasien dengan Makanan Biasa di Rumah Sakit di RS Dr. Sardjito Yogyakarta. Jurnal Gizi Klinik Indonesia. 2005; 1(3):108-112.

4. Irawati. Analisis Sisa Makanan dan Biaya Sisa Makanan Pasien Skizofrenia Rawat Inap di Rumah Sakit Jiwa Madani Palu. Jurnal Gizi Klinik Indonesia. 2010; 6(3):123-131.

5. Kementrian Kesehatan RI. Pedoman Penyusunan Standar Pelayanan Minimum di Rumah Sakit. Jakarta: Dirjen BUK Kemenkes RI; 2012.

6. Aula LE. Faktor-faktor yang Berhubungan dengan Terjadinya Sisa Makanan Pada Pasien Rawat Inap di Rumah Sakit Haji Jakarta. 2011. Available from: http:// repository.uinjkt.ac.id/dspace/handle/123456789/181212

7. Dian B. Hubungan Penampilan Makanan dan Faktor Lainnya Dengan Sisa Makanan Biasa Pasien Kelas 3 Seruni RS Puri Cinere Depok bulan April-Mei 2012 (skripsi). Jakarta : Universitas Indonesia; 2012

8. Kusumayanti, Hamam H, Susetyowati. Faktor-faktor yang Mempengaruhi Kejadian Malnutrisi Pasien Dewasa di Ruang Rawat Inap Rumah Sakit. Jurnal Gizi Klinik Indonesia. 2004;1(1): 9-17.

9. Comstock EM, St Pierre RG, Mackiernan YD. Measuring Individual Plate Waste in School Lunches. Visual Estimation and Children's Ratings vs. Actual Weighing of Plate Waste. Journal of the American Dietetic Association. 1981;79(3):290-296.

10. Murwarni. Penentuan Sisa Makanan Pasien Rawat Inap dengan Metode Taksiran Visual Comstock di RSUP Dr. Sardjito Yogyakarta. (tesis). Yogyakarta : Universitas Gadjah Mada; 2001.

11. Kementerian Kesehatan RI. Angka Kecukupan Gizi yang Dianjurkan Bagi Bangsa Indonesia. Jakarta: Kemenkes RI; 2014.

12. Nuryati P. Hubungan Antara Waktu Penyajian, Penampilan dan Rasa Makanan dengan Sisa Makanan pada Pasien Rawat Inap Dewasa di RS Bhakti Wira Tamtama Semarang. 2008. UNIMUS Digital Library Universitas Muhammadiyah Semarang. Available from: http://digilib. unimus.ac.id

13. Aritonang I. Penyelenggaraan Makanan, Manajemen Sistem Pelayanan Gizi Swakelola dan Jasaboga di Instalasi Gizi Rumah Sakit. Yogyakarta: Leutika; 2012.

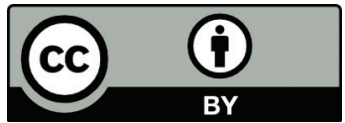

This work is licensed under a Creative Commons Attribution 